\title{
Thermal contact conductance of nominaly flat surfaces
}

\section{H. Yüncü}

Published online: 25 September 2007

(c) Springer-Verlag 2007

Erratum to: Heat Mass Transfer (2006) 43:1-5

DOI 10.1007/s00231-006-0087-9

The original version of this article unfortunately contained errors. The following typos occurred in the article:

1. The second column in Table 1 should be:

$\overline{\text { Micro hardness }\left(\mathrm{N} / \mathrm{m}^{2}\right)}$

$1.53 \times 10^{9}$

$7.26 \times 10^{8}$

$6.08 \times 10^{8}$

$1.12 \times 10^{9}$

2. The values in the last column of Table 2 should be multiplied by ten $(\times 10)$.

3. The unit of Contact Conductance in Table 3 should be $\mathrm{W} / \mathrm{cm}^{2} \mathrm{~K}$.

The online version of the original article can be found under doi:10.1007/s00231-006-0087-9.

H. Yüncü $(\bowtie)$

Mechanical Engineering Department,

Middle East Technical University,

06531 Ankara, Turkey

e-mail: hafit@metu.edu.tr 